\title{
POLYSPERMIC FERTILIZATION OF HAMSTER EGGS IN VITRO
}

\author{
C. BARROS, A. M. VLIEGENTHART AND L. E. FRANKLIN \\ Laboratory of Embryology, Institute of Biological Sciences, \\ Catholic University of Chile, Santiago, Chile, and \\ Delta Regional Primate Research Center, Tulane University, \\ Covington, La. 70433, U.S.A.
}

(Received 26th Fuly 1971, accepted 1st September 1971)

The mechanisms for the prevention of polyspermy in mammalian eggs appear to be associated with the development of the so-called 'zona reaction' (Braden, Austin \& David, 1954) and with the development of a vitelline surface block to polyspermy (Austin \& Braden, 1956). The time required for the development of the zona reaction has been estimated to be not less than $10 \mathrm{~min}$ and not more than $1 \frac{1}{2}$ to $2 \mathrm{hr}$ (Braden et al., 1954).

Hamster eggs recovered from mated females show a low incidence $(1.6 \%)$ of polyspermy (Austin \& Braden, 1956) while eggs fertilized in vitro show a high incidence, often as high as $100 \%$ (Yanagimachi \& Chang, 1964; Barros \& Austin, 1967; Barros, 1968b; Yanagimachi, 1969).

It has not been established whether the high incidence of polyspermy in vitro is due to the penetration of several spermatozoa at the same time or to a continuous flow of spermatozoa into the eggs. This work was aimed at elucidating the problem.

Spermatozoa preincubated for $4 \mathrm{hr}$ at $37^{\circ} \mathrm{C}$ in a mixture of tubal fluid, cumulus masses and $0 \cdot 15 \mathrm{M}-\mathrm{NaCl}$ (buffered to $\mathrm{pH} \mathrm{7.60)}$ ) become fully capacitated, so that when new, freshly induced, superovulated eggs are added to the sperm suspension, sperm penetration starts almost immediately (Barros \& Austin, 1967; Barros, 1968a, b, c). In the present work, spermatozoa were capacitated as described above and freshly ovulated eggs (recovered $14 \mathrm{hr}$ after the injection of $\mathrm{HCG}$ ) were added to the sperm suspension and incubated for periods of 1,2 and $4 \mathrm{hr}$. In each experiment, eggs were removed from the incubation medium at two different intervals, i.e. at 1 and 2 , and 1 and 4 , and at 2 and $4 \mathrm{hr}$. At the end of the incubation period, the eggs were repeatedly sucked in and out of a small bore pipette to remove spermatozoa attached to the surface of the zona pellucida, then mounted between a slide and coverslip, and examined with a phase-contrast microscope for penetration of spermatozoa into the vitellus.

The results show (Table 1) that while $50 \%$ of the eggs are monospermic $1 \mathrm{hr}$ after being exposed to the capacitated sperm suspension, only $10 \%$ of eggs are monospermic $4 \mathrm{hr}$ after entering the suspension. In the column labelled 'more than four sperm.', eggs examined at 1 or $2 \mathrm{hr}$ contained between five and ten spermatozoa whereas those examined at $4 \mathrm{hr}$ contained numbers of 
spermatozoa that sometimes were almost impossible to count. These results seem to indicate that under conditions in vitro, polyspermy can occur as a result of a simultaneous penetration by several spermatozoa and also as a result of a continuous flow of spermatozoa into the egg within a period of at least $4 \mathrm{hr}$. The presence of male pronuclei in different stages of development within a polyspermic egg also supports this conclusion. All penetrated eggs examined showed signs of activation in the breakdown of the cortical granules and the resumption of the second meiotic division. Moreover, the mode of fertilization (sperm penetration and subsequent egg activation and formation of pronuclei) in these polyspermic eggs did not differ from that in eggs recovered from mated females described by Austin (1956) and Austin \& Bishop (1958).

The zona reaction, which appears to be efficient in hamster eggs in vivo (Austin, 1956), might have been affected by the conditions of the culture medium (Barros \& Austin, 1967). Bavister (1969) found a close correlation between

TABLE 1

NUMBER OF EGGS WITH DIFFERENT NUMBERS OF SPERMATOZOA 1, 2 AND 4 HR AFTER EXPOSURE TO CAPACITATED SPERMATOZOA

\begin{tabular}{|c|c|c|c|c|c|c|c|c|}
\hline \multirow{3}{*}{$\begin{array}{l}\text { Hours after } \\
\text { exposure to } \\
\text { spermatozoa }\end{array}$} & \multirow{3}{*}{$\begin{array}{c}\text { Total no. of } \\
\text { eggs } \\
\text { exposed }\end{array}$} & \multirow{3}{*}{$\begin{array}{l}\text { Total no. of } \\
\text { penetrated } \\
\text { eggs }\end{array}$} & \multicolumn{6}{|c|}{ No. of penetrated eggs with: } \\
\hline & & & $\begin{array}{c}\text { One } \\
\text { sperm. }\end{array}$ & $\begin{array}{c}\text { Two } \\
\text { sperm. }\end{array}$ & $\begin{array}{l}\text { Three } \\
\text { sperm. }\end{array}$ & $\begin{array}{c}\text { Four } \\
\text { sperm. }\end{array}$ & \multicolumn{2}{|c|}{$\begin{array}{l}\text { More than } \\
\text { four sperm. }\end{array}$} \\
\hline & & & No. $\%$ & No. $\%$ & No. $\%$ & No. $\%$ & No. & $\%$ \\
\hline $\begin{array}{l}1 \\
2 \\
4\end{array}$ & $\begin{array}{l}341 \\
199 \\
282\end{array}$ & $\begin{array}{l}158 \\
171 \\
258\end{array}$ & $\begin{array}{ll}78 & 50 \\
49 & 29 \\
25 & 10\end{array}$ & $\begin{array}{ll}25 & 16 \\
36 & 21 \\
38 & 15\end{array}$ & $\begin{array}{ll}19 & 12 \\
28 & 16 \\
28 & 11\end{array}$ & $\begin{array}{ll}19 & 12 \\
19 & 11 \\
25 & 10\end{array}$ & $\begin{array}{r}16 \\
39 \\
142\end{array}$ & $\begin{array}{l}10 \\
23 \\
55\end{array}$ \\
\hline
\end{tabular}

polyspermy and the $\mathrm{pH}$ of the culture medium. Higher incidences of polyspermic eggs were found at higher $\mathrm{pH}$ values. However, it is also possible that the reaction did occur but was insufficient to prevent the entry of more than one spermatozoon owing to the large number of spermatozoa attaching to the zona surface simultaneously. On the other hand, the fact that the vitelline surface block to polyspermy seems to be rather slow in hamster eggs (Barros, $1968 \mathrm{~b}$ ) could well account for continuous sperm entry into the vitellus.

Eggs recovered from mated females are usually monospermic. Due to the lack of synchrony in sperm penetration of eggs in vivo, the chances of recovering eggs with spermatozoa penetrating the zona pellucida are very scarce. Thus, many stages of the early events of fertilization, such as the changes of the sperm head during and before its passage through the zona pellucida, can be easily missed. On the other hand, the fertilization technique in vitro provides the means to overcome this problem, not only because the eggs can be made polyspermic but also because, as shown here, there is a continuous passage of spermatozoa into the eggs and the chances to study the different stages of sperm entry are greatly enhanced. These characteristics of the technique are the reasons why it has been so useful in studies of the fine structure of the early events of mammalian fertilization (Barros, Bedford, Franklin \& Austin, 1967; Barros \& Franklin, 1968; Yanagimachi \& Noda, 1970a, b, c; Franklin, Barros \& Fussell, 1970). 
A similar polyspermic system was used in the ultrastructural studies of fertilization of marine invertebrates (see Colwin \& Colwin, 1967). Moreover, Longo \& Anderson (1970) have shown that differences in monospermic and polyspermic fertilization in sea urchin are quantitative rather than qualitative.

There is no reason to believe that the ultrastructural changes observed in mammalian spermatozoa before and during fertilization might be different in monospermic and polyspermic fertilization. Hamster eggs fertilized in vitro contain very few supplementary spermatozoa (Barros, 1968b), indicating that once a spermatozoon has crossed the zona pellucida, it will probably enter the egg cytoplasm.

The preceding evidence stands in opposition to arguments raised by Zamboni (1971) that many of the ultrastructural studies which have taken advantage of the technique in vitro would not correspond to observations of the fertilizing spermatozoon, but of supernumerary spermatozoa, i.e. spermatozoa which are at, or in, the cumulus cells, the zona pellucida or the perivitelline space of an activated egg (Stefanini, Oura \& Zamboni, 1969), or of dislocated or degenerated spermatozoa. We think that they might correspond to supernumerary spermatozoa as defined by Austin \& Walton (1960), i.e. spermatozoa found within the egg cytoplasm of a polyspermic egg.

The loss of the acrosome as a prerequisite to sperm penetration of the mammalian egg was first reported and illustrated by Austin \& Bishop (1958). Our observations are consistent with that report since in every egg examined we never saw a spermatozoon in the thickness of the zona pellucida or in the perivitelline space, with an intact acrosome. Thus, it is difficult to understand the doubts raised by Zamboni (1971) with regard to the loss of the acrosome of spermatozoa that are in, or about to enter, the zona pellucida. Although we accept the possibility of species differences between the mouse on the one hand and the hamster and rabbit on the other, we believe that the vesicles shown in photograph No. 6 (Stefanini et al., 1969), on which Zamboni bases his main argument, do not correspond to the vesicles of the acrosomal cap shown in the works by Barros et al. (1967), Bedford (1967, 1968), Yanagimachi \& Noda (1970a) or Franklin et al. (1970). They might well correspond to the vesiculation of part of the equatorial segment as was reported by Barros \& Franklin (1968) for hamster spermatozoa lying in the perivitelline space.

This work was partially supported by Grants from The Rockefeller Foundation, from CONICYT and from the Catholic University of Chile, and from Grants NIH HD 0423302 and NIH FR 00164-09 of the National Institutes of Health, Department of Health, Education and Welfare. The serum gonadotrophins were kindly provided by Mr Andrés Silva from Organon Laboratories.

\section{REFERENCES}

Austin, C. R. (1956) Ovulation, fertilization and early cleavage in the hamster (Mesocricetus auratus). Jl R. microsc. Soc. 75, 141.

Austin, G. R. \& Bishop, M. W. H. (1958) Role of the rodent acrosome and perforatorium in fertilization. Proc. R. Soc. B, 149, 241.

Austin, G. R. \& BRADEN, A. W. H. (1956) Early reactions of rodent egg to spermatozoon penetration. F. exp. Biol. 33, 358. 
Austin, C. R. \& Walton, A. (1960) Fertilisation. In: Marshall's Physiology of Reproduction, Ed. A. S. Parkes. Vol. 1, pt 2, p. 310 . Longmans Green, London.

BARros, C. (1968a) In vitro capacitation of golden hamster spermatozoa. Anat. Rec. 160, 310.

Barros, C. (1968b) An in vitro study of sperm capacitation, the sperm acrosome reaction and fertilization in the golden hamster (Mesocricetus auratus). Dissertation, Tulane University.

Barros, G. (1968c) In vitro capacitation of golden hamster spermatozoa with the Fallopian tube fluids of the mouse and rat. $\mathcal{F}$. Reprod. Fert. 17, 203.

Barros, C. \& Austin, C. R. (1967) In vitro fertilization and the sperm acrosome reaction in the hamster. 7. exp. Zool. 166, 317.

Barros, G., Bedford, J. M., Franklin, L. E. \& Austin, G. R. (1967) Membrane vesiculation as a feature of mammalian acrosome reaction. $\mathcal{F}$. Cell Biol. 34, C1.

Barros, C. \& Franklin, L. E. (1968) Behaviour of the gamete membranes during sperm entry into the mammalian egg. 7. Cell Biol. 37, C13.

Bavister, B. D. (1969) Environmental factors important for in vitro fertilization in the hamster. $\mathcal{J}$. Reprod. Fert. 18, 544.

BEDFORD, J. M. (1967) Experimental requirement for capacitation and observations on ultrastructural changes in rabbit spermatozoa during fertilization. 7. Reprod. Fert., Suppl. 2, 35.

BeDford, J. M. (1968) Ultrastructural changes in sperm head during fertilization in the rabbit. $A m$. J. Anat. 123, 329.

Braden, A. W. H., Austin, G. R. \& David, H. A. (1954) The reaction of the zona pellucida to sperm penetration. Aust. 7. biol. Sci. 7, 391 .

Colwin, L. H. \& Colwin, A. L. (1967) Membrane fusion in relation to sperm-egg association. In: Fertilization, Vol. 1, p. 295. Eds. C. B. Metz and A. Monroy. Academic Press, New York.

Franklin, L. E., Barros, C. \& Fussell, E. N. (1970) The acrosomal region and the acrosome reaction in sperm of the golden hamster. Biol. Reprod. 3, 180.

Longo, F. J. \& Anderson, E. (1970) The effects of nicotine on fertilization in the sea urchin Arbacia punctulata. 7. Cell Biol. 46, 308.

Stefanini, M., OURA, C. \& Zamboni, L. (1969) Ultrastructure of fertilization in the mouse. 2 Penetration of sperm into the ovum. F. submicr. Cytol. $1,1$.

YaNAGIMAGHI, R. (1969) In vitro capacitation of hamster spermatozoa by follicular fluid. $\mathcal{F}$. Reprod. Fert. 18, 275.

Yanagimachi, R. \& Ghang, M. G. (1964) In vitro fertilization of golden hamster ova. F. exp. Zool. 156, 361.

YanAgimachi, R. \& NoDA, Y. D. (1970a) Ultrastructural changes in the sperm head during fertilization. F. Ultrastruct. Res. 31, 465.

YANAgimachi, R. \& NodA, Y. D. (1970b) Physiological changes in the post nuclear cap region of mammalian spermatozoa: a necessary preliminary to the membrane fusion between sperm and egg cells. 7 . Ultrastruct. Res. 31, 486.

YANAGIMACHI, R. \& NODA, Y. D. (1970c) Electron microscope studies of sperm incorporation into golden hamster egg. Am. J. Anat. 128, 429.

Zамвoni, L. (1971) Acrosome loss in fertilizing mammalian spermatozoa: a clarification. 7 . Ultrastruct. Res. 34, 401 . 